\title{
The influence of old leather tannery district on chromium contamination of soils, water and plants
}

\author{
Agnieszka Wolińska*, Zofia Stępniewska, Rafał Włosek \\ Department of Biochemistry and Environmental Chemistry, The John Paul II Catholic University of Lublin, Institute of Biotechno- \\ logy, Lublin, Poland; ${ }^{*}$ Corresponding Author: awolin@kul.lublin.pl
}

Received 12 December 2012; revised 15 January 2013; accepted 28 January 2013

\begin{abstract}
The paper demonstrates the actual level of chromium contamination at the site of the old tannery waste lagoon in Serniki community (SE Poland). Despite the fact that since 1994 this area is not exploited, the chromium presence is still detected in soil, water and plants. The current study is the $4^{\text {th }}$ phase (after 1989, 2001 and 2004) of checking and controlling the chromium concentration in this territory. The chromium content was assessed after soil and plant mineralization using FAAS method. Total chromium concentrations in soil samples reached values of $2.25-18.25 \mathrm{mg} \cdot \mathrm{kg}^{-1}$ dry mass. Levels of chromium in water samples ranged between 0.008 and $0.017 \mathrm{mg} \cdot \mathrm{dm}^{-3}$ for Wieprz River and the trough, situated in the tannery centre, respectively. Absorption of chromium by plants depended from the plant species. The highest $\mathrm{Cr}$ content in the stalks of Oenothera biennis, whilst the lowest in Phragmites australis were detected. Finally, it was assumed that soil chromium content noted in 2009 was by $42 \%-83 \%$ lower in relation to the data from 2004. Consequently, nowadays the tannery waste lagoon site is not so threat to the health of local residents and to the surrounding ecosystem.
\end{abstract}

Keywords: Chromium; Soil Pollution; Tannery Wastes; Chromium Accumulation

\section{INTRODUCTION}

Chromium is a heavy metal which presence in soil, water and atmosphere can be hazardous to the natural environment [1-3]. Therefore, knowledge of the transport and transformation of this element in the soil environment is important for predicting threats from its presence [4].

Chromium is commonly used in various industries such as metallurgical, refractory, chemical pigments, electroplating and tanning $[5,6]$. One of the major emerging problems of the tanning industry is the disposal of chromium-contaminated sludge that is produced as byproduct of the wastewater treatment [5]. The world production of chromium is in the order of $10^{7}$ tons per year; $60 \%-70 \%$ is used in alloys, including stainless steel, and $15 \%$ is used in chemical industrial processes, mainly leather tanning, pigments and electroplating [7,8].

The migration of chromium in soils and surface- or ground-waters, from its source of pollution, and its toxicity mainly depends on its speciation [6]. Its commonly existing forms are trivalent and hexavalent chromium [2,3]. In oxidized $\mathrm{Cr}$ (VI) form, chromium is highly soluble in water, and therefore mobile, whereas the reduced $\mathrm{Cr}$ (III) form is almost insoluble in water and thus immobile $[4,9,10]$. Hexavalent chromium is very toxic, and it can be an inhaled carcinogen, poisonous to humans and other mammals, whereas trivalent chromium is an essential nutrient as mineral supplement $[1,3,9,11]$.

Values of chromium are strongly related to $\mathrm{pH}$ and redox potential (Eh) conditions [4]. Most of authors demonstrated that $\mathrm{Cr}(\mathrm{VI})$ is stable in the more oxidising environment with Eh level above $600 \mathrm{mV}$ and $\mathrm{pH}$ above $6.0[1,12,13]$. Under conditions of $\mathrm{pH} 3$ to 7 and $\mathrm{Eh}$ from -200 to $500 \mathrm{mV}$ compounds of $\mathrm{Cr}(\mathrm{VI})$ tend to reduce to more thermodynamically stable $\mathrm{Cr}(\mathrm{OH})_{3}[4,14]$. So, under appropriate $\mathrm{pH}$ and $\mathrm{Eh}$ conditions as well as in the presence of reducing or oxidising agents one form of chromium can transform to another $[1,3]$. The reduction of highly toxic $\mathrm{Cr}$ (VI) to the less toxic $\mathrm{Cr}$ (III) is likely to be useful for the remediation of contaminated waters and soils [9]. It was also indicated that $\mathrm{Cr}$ (III) can be transformed to $\mathrm{Cr}$ (VI) mainly inside root cells, and/or in the aerial part of the plant, however, roots accumulate 10 100 times more chromium than shoots and other plants tissues $[7,8]$. As a result of this, there is observed an inhibition of growth, respiration activities and photosynthesis $[8,9]$. Also progressive stages of chlorosis and necrosis are the symptoms of chromium toxicity in plants [7]. There are however still conflicting results regarding, 
which form of chromium is taken up and accumulated by plants $[7,8,15]$. Some authors considered that both translocation as accumulation of chromium inside the plant depends on the oxidation state of the supply and/or on the plant species $[8,15,16]$.

Yet, among heavy metals, chromium has been paid much less attention compared to, e.g., cadmium copper, zinc, lead etc. One of reasons is that this element is constantly considered as a "local source" contaminant, whilst the second is that the dominant naturally occurring form of chromium, $\mathrm{Cr}_{2} \mathrm{O}_{3}$, is known essentially immobile and non-toxic in the environment [10].

Thus, based on above presented assumptions we have started a monitoring program aiming to assess the actual chromium accumulation in the soils, waters and plants of a tannery waste lagoon vicinity in SE Poland.

Our interest was also connected with chromium transformations in soils in the $\mathrm{pH}$ and Eh conditions, described in the prsented tannery waste lagoon site. By realized measurements of $\mathrm{pH}$ and $\mathrm{Eh}$ in the soil samples the estimation of the dominant form of chromium was possible.

\section{MATARIALS AND METHODS}

\subsection{Site Location and Description}

In the current study the tannery waste lagoon (6 ha) in Lubartów (SE part of Poland), located in Serniki community $\left(51^{\circ} 26^{\prime} \mathrm{N} 22^{\circ} 40^{\prime} \mathrm{E}\right)$ has been studied. The storage yard is situated both in a basin as in the direct neighbourhood of the Wieprz River (approx. $50 \mathrm{~m}$ away) and cultivated fields [1]. In the active period (1970-1994) more than $200,000 \mathrm{t}$ of tannery waste, containing $5 \%$ $10 \%$ of $\mathrm{Cr}_{2} \mathrm{O}_{3}$ were produced [6]. High chromium level in wastes deposit results from the application of chromal $\mathrm{Cr}(\mathrm{OH}) \mathrm{SO}_{4}$ (chromium (III) hydroxysulfate), used for protein denaturation in the amount of more than ten thousand tons per year. The second problem was the fact that the tannery waste lagoon was not appropriately secured. Its bottom was not sealed, and this still causes problems connected with the possibility of leaching the harmful substances getting away from it. Consequently, even at present (15 years after closing the Lubartów tannery) a migration of chromium from deposited wastes to the soil and ground water has taken place.

Lubartów tannery was declared insolvent on September 1998. During past 10 years the tannery waste lagoon has undergone reclamation twice (in 2001 and 2005) by covering the top of the storage layer by rocks originating from Bogdanka coal mine. Phytoremediation method was also applied by introducing pine plantings.

In 1989 the old tannery waste lagoon site was first examined for chromium contamination. After 10 years the level of chromium contents in soils, waters and plants were re-analysed [17]. Five years later (in 2004) environmental samples (soils, plants and water) were investigated again [6]. So, the current study is the fourth phase of monitoring the chromium concentration at this site.

\subsection{Samples Collection}

The study material was collected in October 2009 at different distances from the tannery dumping ground (Table 1).

The soil sampling points are numbered from 1 to 7 , depending from their location (Figure 1). Soil samples were taken from the surface layer $(0-20 \mathrm{~cm})$.

Plant samples: leaves of Quercus petraea (DB) and stalks of Oenothera biennis (WD), Juncus sp. (S) and Phragmites australis (TP), representatives for this place were also tested. Water samples were collected from the Wieprz River and the trough situated in the centre of waste deposit (see Figure 1).

\subsection{Mineralization of Soil and Plant Samples}

Under laboratory conditions the soil samples were

Table 1. The distance of soil sampling points from the centre of the tannery waste lagoon.

\begin{tabular}{cc}
\hline $\begin{array}{c}\text { Number of soil } \\
\text { sample }\end{array}$ & $\begin{array}{c}\text { The distance form the tannery waste centre } \\
(\mathrm{m})\end{array}$ \\
\hline 1 & 102 \\
2 & 96 \\
3 & 48 \\
4 & 128 \\
5 & 256 \\
6 & 80 \\
7 & 230 \\
\hline
\end{tabular}

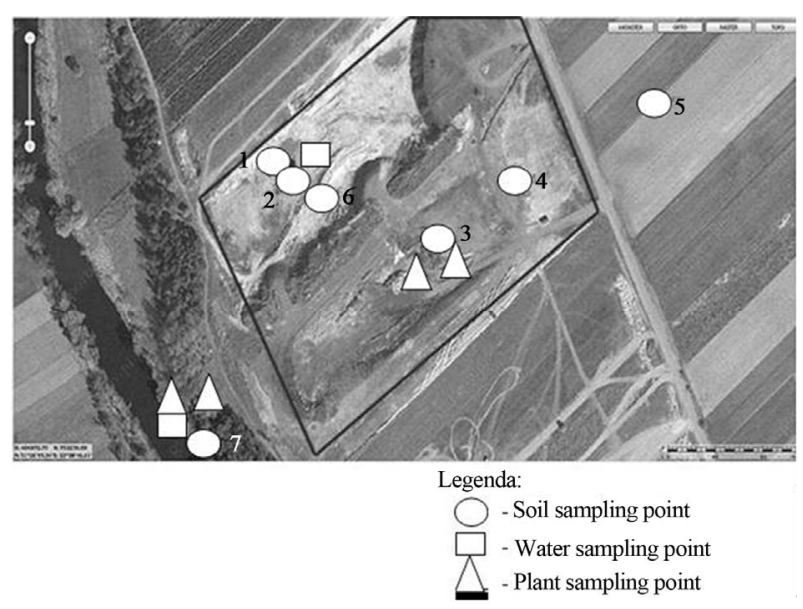

Figure 1. Aerial view of the tannery waste lagoon with marked sample points (maps.geoportal.gov.pl). 
dried at $105^{\circ} \mathrm{C}$ for $24 \mathrm{~h}$ and after that sifted and weighed. Both soil as plant samples were mineralized. Samples $(0.5 \mathrm{~g})$ were digested using the mixture of concentrated $\mathrm{HNO}_{3}$ and $\mathrm{HF}$ and performed (4 min, temp. $150^{\circ} \mathrm{C}$ ) in open microwave system (Maxidigest MX 4350, Prolabo). After filtration the extracts were diluted with distilled water to the final volume of $50 \mathrm{ml}$.

\subsection{Total Chromium Concentration Measurements}

Environmental samples (water, plants and soils) were analysed at $\lambda=359.3 \mathrm{~nm}$ for total chromium concentration by AAS technique, with flame atomisation-FAAS (Z-8200, HITACHI), in three replications. Total chromium concentration was expressed as element content in dry mass of the soil $\left(\mathrm{mg} \cdot \mathrm{Cr} \cdot \mathrm{kg}^{-1}\right)$.

\subsection{Determination of $\mathrm{pH}$ and Eh}

The $\mathrm{pH}$ and Eh were determined potentiometrically using a multifunctional potential meter pIONneer 65 (Radiometer Analytical S.A., France), equipped with a following electrodes: glass $\mathrm{pH}$ electrode-(Cartrode $\mathrm{pH}$ E16M340) and combined platinum and $\mathrm{Ag} / \mathrm{AgCl}$ (reference) electrode (E31M004) — for Eh. Each measurement was replicated three times.

\section{RESULTS AND DISCUSSION}

\section{1. $\mathrm{pH}$ and Eh Values in the Soil Samples}

Values of $\mathrm{pH}$ and $\mathrm{Eh}$ in the soil samples taken from different points of the old tannery waste lagoon are presented in Figure 2. Generally, Eh level varied between $266-510 \mathrm{mV}$, reaching the highest values in soil sample 5 - taken from neighbouring cultivated field.

The lowest redox potential level $(266-281.3 \mathrm{mV})$ in soil sample 6-situated in the central point of the lagoon and sample 7, located nearby Wieprz River was noted.

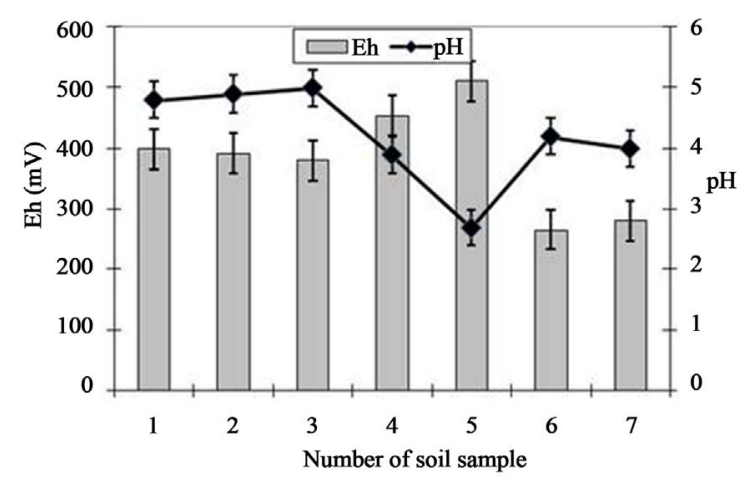

Figure 2. pH values and redox potential (Eh) level at investigated soil samples. Average values with standard deviations are presented.
Soil $\mathrm{pH}$ represented acidic conditions (2.7 - 5.4), characteristic for sandy soils with small CEC (cation exchange capacity) and high $\mathrm{H}^{+}$saturation. Sandy soils predominate at investigated tannery waste lagoon area [1]. Moreover, decrease of $\mathrm{pH}$ to the value of 2.6 resulted in Eh increase to $510 \mathrm{mV}$. This trend is compatible with earlier observations $[1,4,18,19]$. Presented range of Eh is characteristic for good oxygenation conditions with $\mathrm{O}_{2}$, as a main electron acceptor. Furthermore, these Eh values and acidic $\mathrm{pH}$ favoured the dominance of less toxic and immobile $\mathrm{Cr}$ (III) form. It was also pointed out that the main oxidant responsible for oxidation of $\mathrm{Cr}$ (III) in soil was manganese (IV) oxide [4]. Authors observed that the sorption of $\mathrm{Cr}$ (III) on soil decreased in the presence of $\mathrm{MnO}_{2}$, what is probably caused by comparative reaction, which is oxidation of $\mathrm{Cr}$ (III) to $\mathrm{Cr}$ (VI) by $\mathrm{MnO}_{2}$ and also by process of manganese (III) sorption on the soil [4].

\subsection{Chromium Contamination in Water Samples}

Total chromium concentration in water sample originated from Wieprz River reached $0.008 \mathrm{mg} \cdot \mathrm{dm}^{-3}$ and $0.017 \mathrm{mg} \cdot \mathrm{dm}^{-3}$ in the sample taken from the trough situated in the tannery centre. Registered in 2009 water contamination was by $98 \%$ lower from its level in Wieprz River $\left(0.41 \mathrm{mg} \cdot \mathrm{dm}^{-3}\right)$ noted in 2004 [6]. Additionally, in 1989, the chromium concentration in water was estimated at the level of $1.18 \mathrm{mg} \cdot \mathrm{dm}^{-3}$ [1]. Decidedly, in comparison with earlier studies a decreasing trend of the chromium content in Wieprz River was found.

\subsection{Chromium Contamination in Plants}

The highest total chromium concentration was found in the following plant samples (see Figure 3): stalks of Oenothera biennis (WD) and leaves of Quercus petraea (DB), where $\mathrm{Cr}$ content was on the level: $11 \mathrm{mg} \cdot \mathrm{kg}^{-1}$ and $5.5 \mathrm{mg} \cdot \mathrm{kg}^{-1}$ for WD and DB, respectively. In the case of

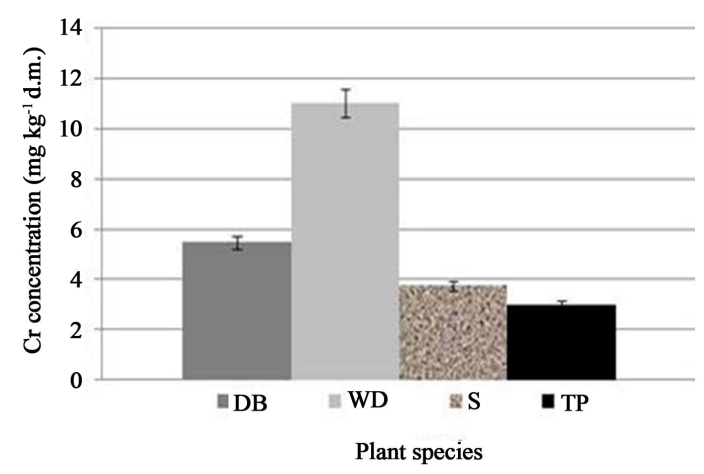

Figure 3. Total $\mathrm{Cr}$ concentration in the plants investigated. Average values with standard deviations are presented. 
stalks of Juncus sp. (S) and Phragmites australis (TP) less ability for chromium absorption was noted, as level of $\mathrm{Cr}$ concentrations remained at the range of $2.75-3.0$ $\mathrm{mg} \cdot \mathrm{kg}^{-1}$.

It was assumed that only a small amount of metal passes through plants [20], however one should remember that the mechanisms of chromium resistance in plant cells have not been properly discovered and described [7]. Suggestion of World Health Organisation (WHO) indicated that the chromium concentration in plants growing in unpolluted soil should not exceed 0.19 $\mathrm{mg} \cdot \mathrm{kg}^{-1}$ [21]. Other authors reported [10] that in normal conditions, chromium concentration in plants is less than $1 \mu \mathrm{g} \cdot \mathrm{g}^{-1}$, but in plants growing on soils treated with tannery waste, concentrations may increase significantly [22]. The study by Isikli et al. [20], who attempted to determine the chromium content in the plants taken from a rural area, exposed to cement factory emissions, indicated that an average chromium concentration was c.a. $167 \mathrm{mg} \cdot \mathrm{kg}^{-1}$. It was also observed that in serpentine soils the mean chromium content was $45 \mathrm{mg} \cdot \mathrm{kg}^{-1}$, but plants growing on these soils may contain up to $100 \mathrm{mg} \cdot \mathrm{Cr} \cdot \mathrm{kg}^{-1}$ [23]. In that context a comparison of our data with these mentioned above demonstrates that tested plant samples were not as highly contaminated with chromium. It may be an effect of phytoremediation treatments realized in 2005 on investigation site. It is known, that the application of plants to decontaminate soils is an initial stage for detoxification of heavy-metal-polluted areas [7]. Phytoremediation based on the ability of the some plant species to absorb, sequester, an/or transform the soil contaminant [24], can be very efficient, particularly in soils with small CEC.

\subsection{Chromium Contamination in Soil Samples}

Large differences in soil chromium concentration were observed in the site investigated, with a very scattered distribution. Total chromium concentrations in soil samples are presented in Figure 4. The highest chromium content is still present in sandy soil samples $1(18.25$ $\left.\mathrm{mg} \cdot \mathrm{kg}^{-1}\right)$ and soil sample $2\left(8.0 \mathrm{mg} \cdot \mathrm{kg}^{-1}\right)$, located in the centre of the old tannery waste lagoon (see Figure 1). At the remaining soil sample points $(3-7)$ chromium concentration not exceeded the level of $5 \mathrm{mg} \cdot \mathrm{kg}^{-1}$.

Finally, comparison of the total $\mathrm{Cr}$ concentration changes (from 2003 to 2009) in a investigated soil samples were done (Figure 5).

A decreasing trend of the chromium concentration with time in the monitored soil points was stated. The highest chromium content was noted in 2004, what may be connected with the second step of tannery waste site restoration-realized in 2005. Results from 2009 showed that chromium concentration in soil samples was lower

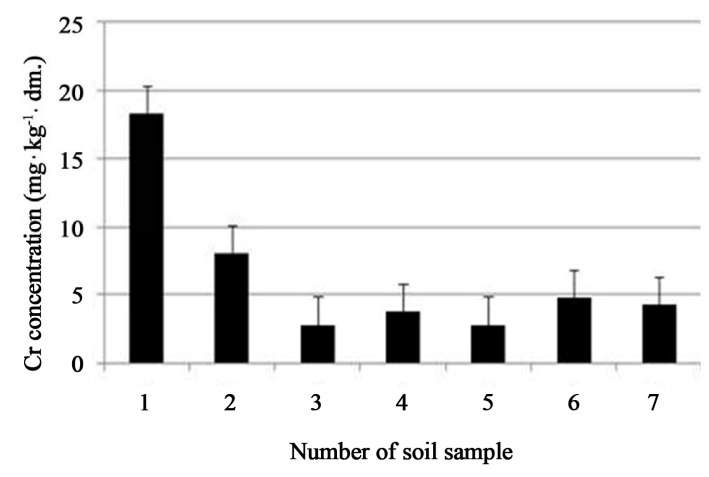

Figure 4. Total $\mathrm{Cr}$ concentration in a marked soil sample points. Average values with standard deviations are presented.

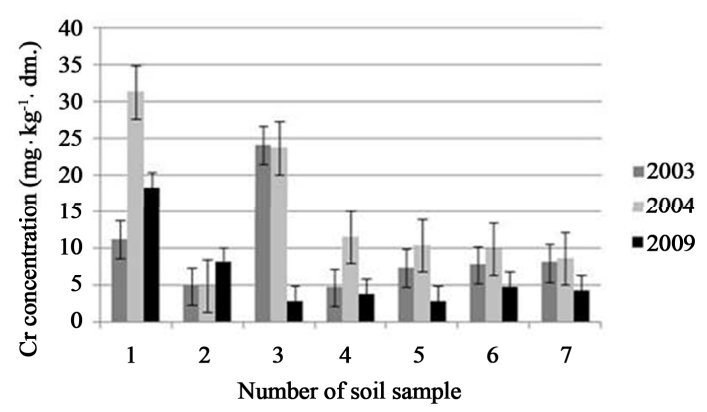

Figure 5. Comparison of the total $\mathrm{Cr}$ concentration changes at 2003, 2004 and 2009 in a soil sample points investigated. Average values with standard deviations are presented.

from these in 2004 by $42 \%$ - $83 \%$ (depending from the soil point location).

In normal conditions, chromium in soils derives from that content in the parent material [10]. Significant chromium enrichment in soils is always of anthropogenic origin. As is reported by WHO [21] the chromium content in soils ranges between 2 and $50 \mathrm{mg} \cdot \mathrm{kg}^{-1}$. The results obtained in the current study have not exceeded the acceptable level of $50 \mathrm{mg} \cdot \mathrm{kg}^{-1}$. Even, the highest chromium concentration stated in the centre of the old tannery waste lagoon $\left(18.25 \mathrm{mg} \cdot \mathrm{kg}^{-1}\right)$, was by $63.5 \%$ lower from WHO limit. Decreasing trend of chromium content observed during last 10 years in the investigated site of tannery lagoon is optimistic, taking into account that the residence time of chromium in soils is estimated to be $10^{3}-10^{4}$ years $[10,25]$.

\section{CONCLUSION}

Our investigations demonstrated that total chromium concentration in soil samples from the vicinity of tannery waste lagoon ranged from 2.25 to $18.25 \mathrm{mg} \cdot \mathrm{kg}^{-1} \cdot \mathrm{dm}$ and not exceeded Polish acceptable level $\left(50 \mathrm{mg} \cdot \mathrm{kg}^{-1}\right)$. Similarly, water contamination in the range from 0.008 $0.017 \mathrm{mg} \cdot \mathrm{dm}^{-3}$ was not an infringement acceptable 
standard $\left(0.05 \mathrm{mg} \cdot \mathrm{dm}^{-3}\right)$. Noted in the current experiment the average concentration of chromium in soil landfill $\left(5.5 \mathrm{mg} \cdot \mathrm{kg}^{-1}\right)$ was about half lower, in comparison with the concentrations noted in 2003 (9.7 $\left.\mathrm{mg} \cdot \mathrm{kg}^{-1}\right)$ and $2004\left(13.8 \mathrm{mg} \cdot \mathrm{kg}^{-1}\right)$. The present study confirmed also previous findings that the chromium absorption from the soil by plants depends on the plant species, as the highest $\mathrm{Cr}$ content was detected in the stalks of Oenothera biennis $\left(11 \mathrm{mg} \cdot \mathrm{kg}^{-1}\right)$, whilst the lowest in Phragmites australis $\left(3 \mathrm{mg} \cdot \mathrm{kg}^{-1}\right)$. Determined soil redox potential (Eh) values, not exceeding the level of $600 \mathrm{mV}$ and $\mathrm{pH} 2.7$ - 5.4 reflected the ranges characteristic and favourable for $\mathrm{Cr}$ (III) dominance. Moreover, it was assumed that applied reclamation methods seemed to be an effective in reduction of $\mathrm{Cr}$ contamination, as nowadays the tannery waste lagoon site is not so threat to the health of local residents and to the surrounding ecosystem.

\section{ACKNOWLEDGEMENTS}

The Authors greatly thank Mr. Artur M. Banach for suggestions which led to language improvement.

\section{REFERENCES}

[1] Stępniewska, Z., Bucior, K. and De Boodt, M. (2001) Chromium and its forms in soils in the proximity of the old tannery waste lagoon. International Agrophysics, 15, 121-124.

[2] Stępniewska, Z., Wolińska, A. and Ziomek, J. (2009) Response of soil catalase activity on chromium contamination. Journal of Environmental Science, 21, 1142-1147. doi:10.1016/S1001-0742(08)62394-3

[3] Santos, E.C., Silva, I.S., Simoes, T.H.N., Simoni, K.C.M., Oliveira, V.M., Grossman, M.J. and Durrant L.R. (2012) Correlation of soil microbial community responses to contamination with crude oil with and without chromium and copper. International Biodeterioration and Biodegradation, 70, 104-110. doi:10.1016/j.ibiod.2012.01.010

[4] Stępniewska, Z., Bucior, K. and Bennicelli, R.P. (2004) The effects of $\mathrm{MnO}_{2}$ on sorption and oxidation of $\mathrm{Cr}$ (III) by soils. Geoderma, 122, 291-296. doi:10.1016/j.geoderma.2004.01.015

[5] Apte, A.D., Verma, S., Tare, V. and Bose, P. (2005) Oxidation of $\mathrm{Cr}$ (III) in tannery sludge to $\mathrm{Cr}$ (VI): Field observations and theoretical assessment. Journal of Hazardous Materials, 121, 215-222. doi:10.1016/j.jhazmat.2005.02.010

[6] Stępniewska, Z., Wolińska, A. and Pióro, W. (2007) Chromium migration in the vicinity of a tannery waste lagoon. Polish Journal of Soil Science, XL/2, 139-145.

[7] Cervantes, C., Campos-Garcia, J., Devars, S., GuatierrezCorrora, F., Loza-Tavera, M., Torres-Guzman, J.C. and Moreno-Sanchez, R. (2001) Interactions of chromium with microorganisms and plants. FEMS Microbiology Reviews, 25, 335-347. doi:10.1111/j.1574-6976.2001.tb00581.x

[8] Polti, M.A., Atjian, M.C., Amoroso, M.J. and Abate, C.M. (2011) Soil chromium bioremediation: Synergic activity of Actinobacteria and plants. International Biodeterioration and Biodegradation, 65, 1175-1181. doi:10.1016/j.ibiod.2011.09.008

[9] Stępniewska, Z. and Wolińska, A. (2005) Soil dehydrogenase activity in the presence of chromium (III) and chromium (VI). International Agrophysics, 19, 79-83.

[10] Bini, C., Maleci, L. and Romanin, A. (2008) The chromium issue in soils of the leather tannery district in Italy. Journal of Geochemical Exploration, 96, 194-202. doi:10.1016/j.gexplo.2007.03.008

[11] Gondek, K., Filipek-Mazur, B. and Koncewicz-Baran, M. (2010) Content of heavy metals in maize cultivated in soil amended with sewage sludge and its mixtures with peat. International Agrophysics, 24, 35-42.

[12] Chin, P.K.F. (1994) Fate and transport of chromium through soil in migration and fate pollutants in soils and subsoils. Institute of Water Research, 96, 61-626.

[13] James, B.R., Petura, J.C., Vitale, R.J. and Mussoline, G.R. (1997) Oxidation-reduction chemistry of chromium: Relevance to the reagulation and remediation of chromate-contaminated soils. Journal of Soil Contamination, 6 , 569-580. doi:10.1080/15320389709383590

[14] Massacheleyn, P.H., Pardue, J.H., De Laune, R.D. and Patrick, W.H. (1992) Chromium redox chemistry in a lower Mississipi Valley bottomland hardwood wetland. Environmental Science and Technology, 26, 1217-1226. doi:10.1021/es50002a611

[15] Mangabeira, P.A.O. (2004) Accumulation of chromium in root tissues of Eichhornia crassipes. Appied Surface Science, 231, 497-501. doi:10.1016/j.apsusc.2004.03.195

[16] Mishra, S., Singh, V., Srivastava, S., Srivastava, R., Srivastava, M.M., Dass, S., Satsangi, G.P. and Prakash, S. (1995) Studies on uptake of trivalent and hexavalent chromium by maize (Zea mays). Food and Chemical Toxicoogy, 33, 393-397. doi:10.1016/0278-6915(95)00004-L

[17] Stępniewska, Z. and Bucior, K. (2001) Chromium contamination of soils, waters, and plants in the vicinity of a tannery waste lagoon. Environmental Geochemistry and Health, 23, 241-245. doi:10.1023/A:1012247230682

[18] Bouda, S. and Issac, K.P. (1986) Influence of soil redox conditions on oxidation of biotite. Clay Minerals, 21, 149157. doi:10.1180/claymin.1986.021.2.04

[19] Gliński, J., Stępniewski, W., Stępniewska, Z., Wło- darczyk, T. and Brzezińska, M. (2000) Characteristic of aeration properties of selected soil profiles from central Europe. International Agrophysics, 14, 17-31.

[20] Isikli, B., Demir, T.A., Urer, S.M., Berber, A., Akar, T. and Kalyoncu, C. (2003) Effect of chromium exposure from a cement factory. Environmental Research, 91, 113118. doi:10.1016/S0013-9351(02)00020-8

[21] World Health Organisation (1988) Chromium environmental health criteria. Geneva.

[22] Barcelo, J. and Poschenrieder, C. (1997) Chromium in plants. In: Canali, S., Canali, F., Tittarelli, P. and Sequi, P., Eds., 
Chromium Environmental Issues, Angelli Press, Milano, 101-130.

[23] Brooks, R.R. (1987) Serpentine and its vegetation: A multidisciplinary approach. Dioscorides Press, Portland.

[24] Huang, J.W. and Cunningham, S.D. (1996) Lead phytoextraction: Species variation in lead uptake and transloca- tion. New Phytologist, 134, 75-84. doi:10.1111/j.1469-8137.1996.tb01147.x

[25] McGrath, S.P. (1999) Chromium and nickel. In: Alloway, B.J., Ed., Heavy Metals in Soils. Blackie Academic \& Professional Press, London, 54-57. 